OSOBA I WOLA

Filozofia Chrześcijańska • Tom 10, Poznań 2013

Unimersytet im. Adama Mickiewicza w Poznaniu • Wydziat Teologiczny

FILEMON TADEUSZ JANKA

Uniwersytet im. Adama Mickiewicza w Poznaniu

Wydział Teologiczny

Zakład Filozofii Chrześcijańskiej

\title{
Wcielenie i zmartwychwstanie - intellectus quaerens fidem
}

Incarnation and Resurrection - Intellectus Quaerens Fidem

\section{WPROWADZENIE}

Nie śniło się filozofom to, co z wiarą, ufnością, w prostocie serca przyjęli ubodzy pasterze, udając się do Betlejem: oto narodził się Bóg! Znany jest prosty, lecz wymowny przekaz ewangelisty Łukasza, mówiący o tym wydarzeniu. Do pasterzy, trzymających straż nocną nad swoją trzoda, przychodzi anioł Pański, zwiastując im radość wielką: ,dziś w mieście Dawida narodził się wam Zbawiciel, którym jest Mesjasz, Pan" (Łk 2,11) ${ }^{1}$. Strach i trwoga mieszały się zapewne z radością i ciekawością. Krótka narada i pospieszne przybycie do Betlejem zaowocowały niezwykłym spotkaniem. Błogosławiona noc, przedziwna nowina. I jakże wielka wiara, która pozwoliła tym prostym ludziom zobaczyć w Dziecięciu złożonym w zwykłym żłobie obiecanego Zbawiciela świata, Króla królów, Tego, którego wyczekiwały pokolenia.

Trzydzieści trzy lata później kontrowersyjny Nauczyciel z Nazaretu, postawiony przed ludzkim trybunałem, zostaje $\mathrm{w}$ pokazowym procesie skazany na haniebną śmierć krzyżową wraz z łotrami. Oskarżony bez winy, niesłusznie osądzony był jednak niewygodnym burzycielem starego porządku, głosicielem wywrotowych teorii, ofiarą systemu i politycznych rozgrywek, w wyniku których swego czasu także Sokrates stracił życie, niebezpiecznym heretykiem tytułującym siebie Synem Bożym, zapewniającym, że Jego królestwo nie jest z tego świata. Dla tych, którzy dali się uwieść wielkim cudom, których dokonywał,

\footnotetext{
${ }^{1}$ Wszystkie biblijne cytaty pochodzą z Biblii Tysiaclecia, wydanie trzecie poprawione.
} 
i wielkim słowom, które wypowiadał, stała się rzecz niepojęta, trudna do wyrażenia słowami! Zbawiciel świata osądzony przez świat i przez świat skazany na śmierć! Nie sposób sobie nawet wyobrazić tego, co mogli wtedy czuć Jego uczniowie. Czyż nie byli wtedy podobni do pustynnych wędrowców, którym pragnienie podsuwa fałszywe obrazy i kreśli iluzję życiodajnej oazy? Oszołomienie, osamotnienie, niedowierzanie, rozczarowanie, zwątpienie i trwoga, zawiedzione nadzieje, dziesiątki pytań bez odpowiedzi, długie godziny rozmyślań, niekończące się rozmowy, powracające wspomnienia wspólnie przeżytych chwil i wciąż brzmiące w uszach niezrozumiałe słowa Mistrza. Kim właściwie był ten człowiek? Świętym mężem, obiecanym Zbawicielem czy wyrafinowanym kłamcą, zwyczajnym oszustem, zręcznym manipulatorem. Straszliwa batalia wiary i rozumu. Piotrowe: „Ty jesteś Mesjasz, Syn Boga żywego” (Mt 16,16) przeciwstawione słowom jednego z uczniów zdążającego do Emaus: „A myśmy się spodziewali, że On właśnie miał wyzwolić Izraela" (Łk 24,21). Kluczowy moment tych wielkich wydarzeń ma jednak dopiero nadejść. Oto bowiem uczniowie Jezusa i niewiasty spieszące Go namaścić stają wobec tajemnicy pustego grobu. Nie ma Pana tam, gdzie Go pochowano. Wkrótce Ten, którego śmierci byli świadkami, ukazuje się im żywy. Niezrozumiałe dotąd słowa pism, które im objaśniał, wydają się jasne, zasłona niewiary i wątpliwości opada z ich oczu, a serca przepełnia radość. I wierzą wbrew rozumowi.

\section{BÓG „PODOBNY” DO CZłOWIEKA}

W tym sformułowaniu uderza wprost dająca się wyczuć rażąca ucho sprzeczność. Bóg podobny do człowieka - ten swoisty oksymoron, trudny do racjonalnego przyjęcia i rozumowego uzasadnienia, wpisuje się jednak w stwórczo-zbawczy plan Boga względem ludzkości. Księga Rodzaju mówi o człowieku uczynionym na „obraz i podobieństwo" (ad imaginem et similitudinem - Rdz 1,26) samego Boga. Idąc tym tokiem myślenia, można by więc rzec, że to człowiek, zgodnie z Jego zamierzeniem, jest „podobny” do Boga, a nie odwrotnie. W czymże bowiem zresztą pełnia doskonałości miałaby być podobna do ułomnego w swej naturze człowieka? Odpowiedzią poniekąd, w bardzo dużym uproszczeniu, jest właśnie owa ułomna, skłonna do grzechu ludzka natura, która sprawiła, że człowiek osadzony w raju sprzeniewierzył się Bogu, oddalił od Niego, zrywając nić przyjaźni. Aby zawiązać ją na nowo, Bóg daje człowiekowi swojego Jednorodzonego Syna Jezusa Chrystusa ${ }^{3}$, który jest prawdziwym, dosko-

\footnotetext{
${ }^{2}$ Zob. T. Janka, Fatszywe rozumienie wolności we wspótczesnym świecie w kontekście praktyk przeciwko życiu, „Studia Franciszkańskie” 2012, nr 22, s. 36-37.

${ }^{3}$ Spór na temat tego, czy Chrystus przyszedłby na świat, gdyby człowiek nie zgrzeszył, toczy się od wieków. Wśród myślicieli średniowiecznych ciekawą odpowiedź na ten temat daje Jan Duns
} 
nałym obrazem Ojca, i dopiero w Nim uwidacznia się cały sens i cel stworzenia człowieka na „obraz i podobieństwo” Boga. W Pawłowym hymnie chrystologicznym pobrzmiewa bezwzględne Chrystusowe pierwszeństwo: „On jest obrazem Boga niewidzialnego - Pierworodnym wobec każdego stworzenia [...] Wszystko przez Niego i dla Niego zostało stworzone. On jest przed wszystkim i wszystko w Nim ma istnienie" (Kol 1,15-17).

$\mathrm{Na}$ miejsce dwóch najbardziej fundamentalnych i doniosłych wydarzeń w historii ludzkości - wcielenia i zbawienia - Bóg wybiera czasoprzestrzeń, w której funkcjonuje człowiek, tzn. osadza je w określonym kontekście historycznym, umiejscawia w czasie i określonej przestrzeni. Innymi słowy, posyła swego Syna na ziemię. Co więcej nie czyni tego w jakiś dziwny, niezrozumiały, abstrakcyjny dla człowieka sposób, lecz pozwala Mu, za sprawą Ducha Świętego, narodzić się jako bezbronne dziecko ze śmiertelnej kobiety, dorastać i żyć w normalnej rodzinie jakich wiele. Nicejsko-konstantynopolitańskie wyznanie wiary głosi, że Syn Boży ,zstąpił z nieba i za sprawą Ducha Świętego przyjął ciało z Maryi Dziewicy i stał się człowiekiem”. Święty Jan w prologu do Ewangelii powie: „A Słowo stało się ciałem i zamieszkało wśród nas" (J 1,14). Staje się rzecz bezprecedensowa $\mathrm{w}$ historii świata. Bóg przyjmuje powłokę cielesną, fizycznie wkracza w materialny, ziemski świat $\mathrm{i}$ - choć jest doskonałym człowiekiem z racji swej dwojakiej natury ${ }^{4}$ - wiedzie zwyczajne życie wśród mieszkańców Palestyny, we wszystkim też stając się podobny do człowieka z wyjątkiem grzechu (por. Hbr 4,15). Doświadcza czysto biologicznych symptomów właściwych ciału - odczuwa głód, pragnienie, zmęczenie, ból. W sferze psychicznej doznaje typowo ludzkich uczuć. Obfituje w nie relacja św. Jana, mówiąca o wskrzeszeniu Łazarza. Jezus miłuje Martę, jej siostrę i Łazarza. Na wieść o chorobie przyjaciela udaje się do niego, lecz przybywa za późno. Łazarz bowiem od czterech dni przebywa w grobie. Ten fakt nie smuci Go szczególnie, a wręcz raduje, gdyż to, czego za chwilę dokona na oczach uczniów, objawi Bożą wszechmoc i pozwoli im uwierzyć. Po ludzku jednak, widząc żałobę i rozpacz bliskich zmarłego, sam rozrzewnia się, wzrusza i płacze (por. J 11,1-43). W Ogrójcu drży, odczuwa trwogę, a Jego duszę przepełnia smutek, wie bowiem, że nieuchronnie zbliża się godzina, w której Syn Człowieczy zostanie wydany w ręce grzeszników, będzie cierpiał okrutną mękę aż po śmierć na Krzyżu (por. Mk 14,32-42).

Jezus zatem poznaje zmysłami, widzi świat ludzkimi oczyma, ma świadomość, wyobraźnię, pamięć, instynkt, intelekt. Jego ziemska egzystencja nie za-

Szkot, twierdząc, że Chrystus przyszedłby niezależnie od ludzkiego przewinienia, gdyż był chciany z miłości dla Niego samego. Zob. T. Janka, Jana Dunsa Szkota pamiętny turniej średniowiecznej filozofii, Poznań 2011, s. 132nn.

${ }^{4}$ Zob. Dwie natury w Chrystusie oraz właściwości obydwóch natur w Chrystusie, w: Breviarium Fidei. Wybór doktrynalnych wypowiedzi Kościoła, red. I. Bokwa, Poznań 2007³, s. 65-66; 112-113 . 
węża się jednak tylko do psychofizycznego bytowania, ale wychodzi ku temu, czego nie można ująć doświadczalnie, jest bowiem, tak jak człowiek, istotą cielesno-duchową̧. Z tą tylko różnicą, że ów pierwiastek duchowy w Chrystusie jest doskonały, gdyż jest On Synem Bożym, jednym z Ojcem, a duchowość doskonała właściwa jest Bogu. Rodzi się wprawdzie i wychowuje w pobożnej, zachowującej prawo Mojżeszowe rodzinie, ma jednak świadomość swej odmienności. Już jako dwunastoletni chłopiec tłumaczy swoim szukającym Go rodzicom, że powinien być w tym, co należy do Jego Ojca (por. Łk 2,48-49). Samym sobą, w każdej sekundzie, minucie, godzinie ziemskiego życia świadczy o Ojcu, pokazuje Go, objawia Go światu. Dokonując cudów, znaków, nauczając, modląc się, pozostaje z Nim w łączności, wszystko czyni w Jego imię. Ta głęboko mistyczna relacja doskonałego umiłowania Syna przez Ojca jest obrazem miłości Chrystusa do człowieka, którego On kocha na wzór Ojca i któremu pokazuje, jak kochać Ojca: ,jak Mnie umiłował Ojciec, tak i Ja was umiłowałem” (J 15,9).

W całej swej wielkości, wyjątkowości, rozumności, głębi bytu, uprzywilejowanej pozycji wśród stworzeń, człowiek nie ma takiego narzędzia poznawczego, które pozwoliłoby mu zrozumieć ten niepojęty fakt: Bóg przychodzi na ziemię jako człowiek, do ludzi zwyczajnych, ubogich, chorych, grzesznych, radujących się i smucących, utrudzonych życiem, doświadczonych przeciwnościami. Przebywa wśród nich, obdarza ich miłością, zrozumieniem, zatroskaniem, współczuciem. Staje się im bliski, dotyka i pozwala się dotykać, słucha i porywa thumy swoją nauka, karmi głodnych, uzdrawia chorych, odpuszcza grzechy, jest gościem w Kanie Galilejskiej, wstępuje do domu Zacheusza, spotyka się z celnikami i nierządnicami. A gdy nadchodzi Jego godzina, oddaje życie za ludzkość, po trzech dniach zmartwychwstając, aby śmierć nie była już kresem, ale początkiem nowego życia. W ten sposób na trwałe wiąże przerwaną grzechem nić przyjaźni.

Wcielenie i zmartwychwstanie chrześcijańskiego Boga - największe tajemnice wiary były, są i pozostaną dla człowieka niezrozumiałe. Nie dają się bowiem logicznie wytłumaczyć, uzasadnić, tym bardziej udowodnić. Stoją w sprzeczności z ludzkim rozumem. Wszechpotężny Bóg, Stwórca świata i człowieka zstępuje z nieba, stając się jednym z ludzi. Odwieczne Boskie Słowo - absolutne, nieskończone, zestawione z ludzkim ciałem - ograniczonym, nietrwałym i przemijającym stanowią paradoks dla kultury greckiej6. Ten sam Bóg, dawca wszelkiego życia, na oczach wielu świadków fizycznie umiera, aby następnie powrócić do świata żywych, „gdyż niemożliwe było, aby ona panowała nad Nim” (Dz 2,24). Nikt z żyjących dotąd tego nie dokonał. Tak trudno to było pojąć bezpośrednim świadkom tych wydarzeń. O ile trudniej było i jest tym, którym prawdy

\footnotetext{
${ }^{5}$ Por. tamże, s. 65-66.

${ }^{6}$ G. Ravasi, Wcielenie i nowoczesność. Analiza kontrapunktu, „Przegląd Uniwersytecki” 2012, nr 5 (139), s. 13.
} 
te głosi się już ponad 2000 lat. Często mają oni w sobie to zasiane w sercu ziarno sceptycyzmu Tomasza, do którego Chrystus powie: „Błogosławieni, którzy nie widzieli, a uwierzyli" (J 20,29). Niewspierany łaską wiary, osamotniony umysł buntuje się przeciwko wydarzeniom po ludzku niemożliwym, próbując zadać im kłam. Plotka o wykradzeniu ciała Jezusa przez Jego uczniów, rozpowiadana przez opłaconych żołnierzy pilnujących grobu, po dzień dzisiejszy zapładnia umysły $\mathrm{i}$ jest dobrym argumentem przeciwko wydarzeniom $\mathrm{z}$ historii zbawienia (por. Mt 28,11-15).

Jak zauważa Benedykt XVI, te dwa punkty - wcielenie i zmartwychwstanie - w których Bóg wkracza bezpośrednio w materialny świat człowieka, są skandalem dla nowożytnego ducha, który miejsce Boga upatruje w sferze idei, myśli, duchowości, nie zaś ziemskiej rzeczywistości. Bóg tu przeszkadza, On tu nie pasuje, to nie miejsce dla Niego. Bóg jednak, jak zauważa papież, włada także materią, inaczej nie byłby Bogiem ${ }^{7}$. Patrząc jedynie przez pryzmat wiary, należy zauważyć, że obecność Boga w materii nie jest niczym sprzecznym czy niedorzecznym. Wydaje się jednak, że nie chodzi tu tylko o kwestię ,pasowania” Boga do materialnego świata człowieka czy władztwa nad nim. W nowożytności uznano Boga jedynie za wytwór ludzkiego umysłu, odmawiając Mu tym samym istnienia w ziemskiej czasoprzestrzeni. W ten sposób owo nowożytne myślenie, którego prekursorem stał się Kartezjusz, ugruntowywane, powielane, obecne w ideologiach wielu poczytnych myślicieli oświecenia i czasów późniejszych, na zawsze zniekształciło prawdę o tym, kim jest Bóg, a w konsekwencji również o tym, kim jest człowiek, prowadząc w ostateczności do słynnego uśmiercenia Boga w poglądach Fryderyka Nietzschego. Aby jednak lepiej zrozumieć ów katastrofalny w skutkach przewrót nowożytnego myślenia, wielki skandal z Bogiem w roli głównej, trzeba choć w kilku zdaniach odwołać się do pojmowania Jezusa w tradycji judaistycznej, spojrzeć w stronę filozofii starożytnej, szczególnie okresu klasycznego, jak również średniowiecznej filozofii, pozostającej pod silnym wpływem chrześcijaństwa.

\section{CHRYSTUS ODRZUCONY PRZEZ NARÓD WYBRANY}

Naród wybrany tak długo czekał na obiecanego Zbawiciela, że kiedy przyszedł, nie potrafił pojąć, że to właśnie On jest Tym, którego przez usta proroków zapowiedział Ojciec. Ponad 2000 lat temu Bóg wypełnił dane słowo, zsyłając na świat Jezusa Chrystusa, aby na drzewie Krzyża dokonało się zbawienie wszystkich ludzi. Dla Żydów jednak Krzyż - święty znak chrześcijan - jest symbolem

\footnotetext{
${ }^{7}$ Por. J. Ratzinger (Benedykt XVI), Jezus z Nazaretu Dzieciństwo, thum. W. Szymona, Kraków 2012, s. 78-79.
} 
słabości i cierpienia, a nawet więcej, zgorszenia ${ }^{8}$. W tradycji judaistycznej bowiem bluźnierca i bałwochwalca, który zawisł na krzyżu, jest przeklęty przez Boga wraz z całym narodem izraelskim. Nie sposób zatem pogodzić dwóch rozbieżnych wizji zbawienia, które głoszą chrześcijanie i Żydzi. Jedni wyznają Jezusa ukrzyżowanego, poniżonego, cierpiącego, który wziął na siebie grzechy ludzkości i w ten sposób dokonał usprawiedliwienia przed Bogiem, drudzy zaś zaprzeczają, że zbawicielem może być ten, kto poniósł śmierć na krzyżu, gdyż jest on przeklęty przez Boga, ponadto nie uznają zastępczego przejęcia win za kogoś i wciąż - jak się wydaje - czekają na tego, który objawi swoją potęgę wśród innych narodów, wywyższy duchowo i politycznie naród Izraela, przyjdzie jako król, któremu będą służyć, nie zaś jako poniżony sługa i niewolnik.

Interpretacja starotestamentalnych znaków, zapowiedzi, proroctw czy przepowiedni mówiących o mającym się narodzić Synu Bożym, judaistyczne wyobrażenia, oczekiwania i nadzieje $\mathrm{z}$ tym faktem związane pozostają, zdaniem Żydów, w głębokiej sprzeczności z rzeczywistością i logiką Krzyża, z Chrystusową nauką, do której odnosi się Nowy Testament. Rygorystycznie wierni prawu Mojżeszowemu odrzucają nakazy nowego prawa, uzasadniając, że jest ono niezgodne z przepisami starego. Tymczasem nie ma przepaści między Bogiem Starego i Nowego Testamentu, który jest jednym i tym samym Bogiem. Nie ma rozłamu między prawem Mojżeszowym a prawem Chrystusowym. Stanowią one logiczną i spójną całość, gdyż Stary Testament jest zapowiedzią i wypełnieniem Nowego. Także Jezus Chrystus jest Tym, na którego czekali wszyscy ufający Bogu, jest poniżonym i umęczonym Królem, Synem Bożym, którego królestwo, jak sam mówi, nie jest $\mathrm{z}$ tego świata.

\section{FILOZOFIA KLASYCZNA - BYT REALNIE I NIEZALEŻNIE ISTNIEJĄCY}

Na pytania, dotyczące początków świata, problemów związanych z jego funkcjonowaniem przed pojawieniem się filozofii, a także w pewnym stopniu w okresach jej istnienia - niejako uzupełniająco - odpowiedź dawały starożytne kosmogonie i teogonie, mity i wierzenia mówiące o powstaniu świata, bogach w nim obecnych i światem rządzących. Przełomowe przejście od mitu do logosu starożytność zawdzięcza Talesowi i jego bardziej rozumowym próbom ujęcia początków świata. Jemu też przypisuje się słynną maksymę, że ,wsszystko jest z wody, a świat jest pełen bogów". Jak jednak rozumieć to z pozoru sprzeczne twierdzenie? Jako próbę pogodzenia umysłowych przekonań z religijnymi dozna-

\footnotetext{
${ }^{8}$ Uzasadnienie, dlaczego Chrystus jest zgorszeniem dla Żydów, podano za: J. Stefański, My głosimy Chrystusa ukrzyżowanego, który jest zgorszeniem dla Żydów...(1 Kor 1,23), „Studia Gnesnensia”, 2011, nr XXV, s. 27-44.
} 
niami? Z pomocą przyjdą tu niewątpliwie zapatrywania innych pierwszych filozofów, także poszukujących pierwszej, prostej, fundamentalnej zasady istnienia świata, substancji, z której powstał. Przywoływany Tales upatrywał ją w wodzie, Anaksymander mówił o bezkresie, Anaksymenes powoływał się na powietrze, Heraklit zaś wspominał o ogniu. Twórcy innych koncepcji początków doszukiwali się w liczbach, cząstkach czy atomach jako budulcu świata. Materia, z której wyłonił się świat, jak jednak w przeważającej większości mniemano, miała w sobie „coś boskiego”, w tym właśnie sensie Talesowski „świat był pełen bogów". Budulec świata musi mieć w sobie boskie atrybuty, takie jak choćby nieśmiertelność, nieskończoność, nieograniczoność czy niezniszczalność. Co ważne, a nad czym rozważać będzie później Arystoteles, owa materia nie była nieruchomą, bezwładną siła, potrzebującą odpowiedniego mechanizmu, aby ją poruszył. Ruch leżał już jakby w jej naturze.

W miarę upływu czasu rozwiązania dotyczące początków świata, proponowane przez pierwszych myślicieli u progu rodzącej się filozofii, wydają się nieco naiwne i lekko nieaktualne. I o ile nie do końca zmieniają się pytania, choć niewątpliwie poszerza się ich krąg, o tyle bardziej złożoną, skomplikowaną, wyrafinowaną i wysublimowaną formę przybierają odpowiedzi. Prawdziwą zaś wirtuozerię osiagną w IV w. p.n.e., kiedy to swój pojedynek gigantów rozpoczną Platon i Arystoteles. Obaj zyskają nieśmiertelność, stawiając sobie filozoficzny „pomnik trwalszy niż ze spiżu”. Obaj podejmą te same kwestie, używając jednak odmiennych narzędzi. Platon skieruje swój wzrok ku temu, co niematerialne i duchowe, Arystoteles zaś opowie się za empiryczno-racjonalnym tłumaczeniem świata.

W Platońskiej, hierarchicznej koncepcji struktury rzeczywistości świat fizyczny postrzegany zmysłowo, plasuje się na ostatnim miejscu. Ponad nim znajdują się odpowiednio: płaszczyzna bytów matematycznych, w tym także dusz, płaszczyzna idei oraz najwyżej - pierwsze i najwyższe zasady. W tej koncepcji istnieje także Demiurg - Rzemieślnik, najwyższy Umysł, najlepszy z bytów rozumnych, najdoskonalsza z przyczyn, stwórca wszechświata w specyficzny sposób oddziałujący na wymienione wyżej elementy. Dla Platońskiego Demiurga, paradygmatem istnienia świata fizycznego staje się świat idei i bytów matematycznych uchwytny jedynie intelektem, w który wpatruje się on, tworząc zmysłową, zmienną rzeczywistość. Sam proces tworzenia rozumiany jest jednak przez Platona odmiennie od tego, który wyłania się z biblijnego obrazu. Demiurg, w przeciwieństwie do chrześcijańskiego Boga, nie tworzy świata ex nihilo, a konstruuje go, jeśli tak można powiedzieć, z zastanych elementów. Jego działanie skupia się bardziej na ich porządkowaniu, formowaniu. Kierując się Dobrem jako najwyższą i jedną z regul, do czego zresztą jest zobowiązany z racji ich hierarchicznej nadrzędności, scala sferę bytu wiecznego ze sferą rzeczywistości zmysłowej, posługując się przy tym właśnie bytami matematycznymi, odgrywający- 
mi w tym akcie rolę pośredniczącą. Mówiąc prościej, Demiurg tworzy świat, biorąc sobie za wzór model, którym jest byt wieczny, aby w ten sposób stworzyć fizyczny świat zmysłowy, który staje się niejako jego obrazem, odbiciem. Stąd przekonanie, że każda ziemska rzecz ma swoje odwzorowanie w nieśmiertelnej idei. Tę koncepcję dwóch połączonych rzeczywistości, w której jedna wiedzie prym nad drugą, doskonale oddaje znana parabola jaskini, w której więźniowie siedzą przykuci łańcuchami do ściany w taki sposób, że nie dostrzegają płonącego za nimi ogniska. Cienie, które czasem widzą na ścianie, wydają się im rzeczywistością. Tylko ten z nich, który zrzuci zniewalające go okowy, opuści jaskinię i przywyknie do światła dnia, pojmie prawdziwą rzeczywistość.

O ile Platon w swoich poglądach ideom i Absolutowi przyznawał a priori realne istnienie, o tyle Arystoteles doszedł do tego drogą a posteriori. Platon pojmował Boga niemalże mistycznie, dla Arystotelesa stał się on jedynie logiczną koniecznością. Platona pochłaniał świat idealny, Arystotelesa zaś bardziej interesował fizyczny. Poddając krytyce Platońską teorię wiecznych zasad i idei, wypracował własne spojrzenie na rzeczywistość ponadzmysłową, uznając, że tym, co jej patronuje, nie jest, jak u Platona, Jedno-Dobro, ale Intelekt. Najwyższy Byt, nazwany przez Stagirytę, pierwszym, Nieporuszonym Poruszycielem, jest Myślą, która myśli i kontempluje samą siebie. Do istnienia owej pierwszej Zasady dochodzi Arystoteles, poszukując substancji niezniszczalnych, którymi są dla niego m.in. ruch i czas. One zaś istnieją właśnie mocą pierwszej Zasady, która staje się gwarantem ich istnienia. O pierwszym Poruszycielu mówi Arystoteles jako o bycie wiecznym, nieruchomym, będącym czystym aktem. Wieczny ruch musi mieć wieczną przyczynę, musi być nieruchomy, gdyż to, co nieruchome, jest absolutną przyczyną tego, co ruchome, musi w końcu być czystym aktem, wolnym od potencjalności, gdyż nią ograniczony mógłby zaprzestać poruszać, przecząc tym samym wiecznemu ruchowi. Odpierając zarzuty i odpowiadając na pytania, jak pierwszy Poruszyciel może poruszać, skoro sam pozostaje niezmiennie nieruchomy, Arystoteles mówi o przyczynowaniu typu celowego - Bóg pociaga jako przedmiot miłości i jako taki jest przyczyną sprawczą.

Choć Bóg Arystotelesa jest pierwszym Poruszycielem, Najwyższym Bytem, to obok Niego istnieją i działają także inni poruszyciele, odpowiedzialni za poszczególne sfery niebieskie. Owa wielość pozaziemskich bytów, obecna w dociekaniach niemalże wszystkich znaczących starożytnych filozofów, jest cechą charakterystyczną politeistycznej umysłowości greckiej, niepozwalającej zdecydowanie przyjmować i wyznawać Boga nad bogami w takim sensie, w jakim mówić o Nim będzie cały świat chrześcijański. Nie można także i nie należy utożsamiać Go z pojęciem Boga w znaczeniu religijnym, gdyż jest on niejako „owocem” empiryczno-racjonalnych przemyśleń i dociekań powstałych na gruncie filozofii. Dla starożytnych określenie „boski” było, jak się zdaje, synonimem tego, co wieczne, niezniszczalne. Boskie były żywioły, z których - zdaniem 
pierwszych filozofów - powstał świat, boskie były dusze, idee Platona, boski był pierwszy Poruszyciel, boskie były sfery niebieskie z całym ich bogactwem. Nowe znaczenie przymiotnik boski zyska w świadomości chrześcijan, gdzie boskość będzie „,zarezerwowana” tylko dla jednego, jedynego, najwyższego, wszechmogącego i najdoskonalszego Bytu, ponad który, jak powie św. Anzelm, czegoś większego już pomyśleć nie można, aby nie popaść w sprzeczność.

\section{FILOZOFIA ŚREDNIOWIECZNA - JEDEN, JEDYNY BÓG}

Wielu starożytnych filozofów przypisywało specyficznie rozumianemu Bogu istnienie niejako naturalne, niepodważalne, obiektywne, niezrelatywizowane tylko do ludzkiego poznania. Jednak Jego postrzeganie bardzo różniło się od obrazu Boga, jaki został objawiony i przyjęty przez chrześcijan. Bóg starożytnych wydawał się jedynie jednym z wielu odwiecznie istniejących, współtworzących strukturę wszechświata elementów, bezosobowym umysłem, bytem odległym, dalekim od człowieka i jego spraw, którego powiązania z ludzkością nie zostały dostatecznie jasno określone.

Fundamentem nowej religii, rodzącej się już w okresie cywilizacji klasycznej, zawiązującego się wokół niej Kościoła, nowej rozwijającej się myśli chrześcijańskiej, która współokreśliła tożsamość Europy, stała się wiara w jednego, jedynego, prawdziwego, wszechmogącego, w pełni doskonałego i osobowego Boga. Starożytna wielość zgodnie z pragnieniem Homera, wyrażonym wersami Iliady: „niedobre jest wielowładztwo, na czele jeden niech będzie", powoli ustępowała miejsca Bogu numerycznie jednemu, choć w trzech osobach Ojca, Syna i Ducha św., i jedynemu, tzn. takiemu, oprócz którego nie było, nie ma i nigdy nie będzie innego. Bogu-Stwórcy wszystkich rzeczy widzialnych i niewidzialnych, absolutnej przyczynie wszystkiego, co istnieje. Bogu bliskiemu człowiekowi, stwarzającemu go na swój obraz i podobieństwo, nawiązującemu szczególną udokumentowaną na kartach Pisma Świętego relację i pozostającemu z nim w niej. Bogu miłosiernemu, przebaczającemu człowiekowi jego niewierność w raju. I w końcu Bogu, który wkracza realnie i namacalnie w historię człowieka w osobie Syna.

Świadomość człowieka średniowiecza jest świadomością obecności Boga, przynależności do Niego, połączoną z przekonaniem o marności własnej i ziemskiego świata $\mathrm{z}$ równoczesną nadzieją na zjednoczenie $\mathrm{z}$ Nim $\mathrm{w}$ wieczności. Istnieje wszak dla Boga, dzięki Bogu i do Boga, jako do ostatecznego i jedynego celu ludzkiego życia, zmierza. W okresie poprzedzającym średniowiecze przejmującymi słowami wyraził to św. Augustyn, mówiąc: „Uczyniłeś nas dla Siebie i niespokojne jest serce nasze, póki nie spocznie w Tobie”. Doda także: „Pragnę znać Boga i duszę. I nic więcej? Nic więcej”. Poznanie Boga, określenie Jego natury, relacji z człowiekiem i światem stanie się dążeniem tak teologii, jak i filozofii średnio- 
wiecznej. W teologii poznanie Go będzie niejako dane w postaci prawd objawienia, na gruncie filozofii zaś zaowocuje m.in. licznymi koncepcjami Boga, w tym dowodami na Jego istnienie. Długo jednak w średniowiecznej nauce prymat w poznaniu Boga przysługiwał nauce świętej. Filozofia o swoją pozycję musiała tu zawalczyć. Uzgodnienie związków między teologią a filozofia, wiarą a rozumem stało się jednym z palących problemów naukowych. Pojawiały się więc z jednej strony zakusy, aby wyznaczyć filozofii rolę służebna, jedynie pomocną w stosunku do teologii i uznać zdecydowany prymat nauki świętej, z drugiej zaś podejmowano próby zmierzające do bardziej lub mniej zdecydowanego odcięcia jednej od drugiej i uznania autonomii obu. W rezultacie obie te dziedziny dopełniały się wzajemnie w poznaniu Boga, zgodnie ze znaną scholastyczną zasadą: wierzę, abym rozumiał, rozumiem, abym wierzył. „Wierzyć” nie negowało „wiedzieć”. Przeciwnie, dla mistrzów scholastycznych, którzy w dużej większości byli tak teologami, jak i filozofami, dowodzenie istnienia Boga nie było odpowiedzią na wątpliwości z tym związane, lecz przekonaniem, że prawdę o Nim można pojąć rozumem. Już św. Augustyn pisał: „zawsze wierzyłem, że istniejesz i że się o nas troszczysz”, jednocześnie na drodze rozumowej poszukiwał Boga, dowodząc, że musi istnieć jakiś wzorzec prawdy, stanowiący odniesienie dla człowieka, i musi istnieć ktoś, kogo wszyscy uznają za wyższego od innych.

Dociekania o Bogu przybierały formę dowodów apriorycznych bądź aposteriorycznych. Bóg jawił się jako idea dana człowiekowi, wpisana w jego świadomość, niezależna od materii, a więc niepodlegająca jej prawom, albo - przeciwnie - Jego śladów poszukiwano w ziemskiej rzeczywistości, upatrując w Bogu przyczynę istnienia bytów niekoniecznych, tzn. takich, których istota nie zawiera istnienia, które istniejąc, istnieć wcale nie muszą. Aprioryczne wnioskowanie św. Anzelma zwane dowodem ontologicznym zakładało istnienie bytu najdoskonalszego, który musi istnieć tak w umyśle, jak i w rzeczywistości. Gdyby bowiem Bóg istniał jedynie $\mathrm{w}$ umyśle człowieka, byłby pozbawiony własności istnienia rzeczywistego, nie byłby więc istotą najwyższą.

Wnioskując $\mathrm{z}$ istnienia bytów przygodnych, swoje pięć tez na istnienie Boga dał także św. Tomasz w postaci dowodu znanego pod nazwą „pięć dróg św. Tomasza z Akwinu" (z ruchu, z przyczynowości sprawczej, z przygodności bytów, ze stopni doskonałości bytów, z celowości). Wszystkie one wskazują na pierwszą przyczynę jako źródło istnienia bytów przygodnych, które same z siebie istnieć nie mogą.

Nigdy to, co zmysłowe i przygodne, nie stanie się punktem wyjścia dla tego, co istotne i ponadzmysłowe. Dowodzenie istnienia Boga, zdaniem Jana Dunsa Szkota ${ }^{9}$, może mieć charakter tylko i wyłącznie aprioryczny. Rozwijając i uzupeł-

${ }^{9}$ Zob. omówienie poszczególnych etapów dowodu na istnienie Boga w: T. Janka, Jana Dunsa Szkota pamiętny turniej..., s. 120nn. 
niając myślenie św. Anzelma, Szkot skonstruował własny, złożony z trzech ściśle powiązanych etapów dowód. W pierwszym, powołując się na zasadę niesprzeczności, wykazał istnienie bytu absolutnie pierwszego w trojakim porządku przyczynowania: sprawczego, celowego i wzniosłego pod względem doskonałości. W drugim dowodził, że ów istniejący byt pierwszy jest Bytem Nieskończonym, w trzecim zaś pokazał, że Byt Nieskończony, aktualnie istniejący jest bytem numerycznie jednym i jedynym. Szkot w swoim dowodzeniu zastosował klasyczne rozumowanie a priori: z możliwości istnienia wnioskując o istnieniu. Jeśli coś może istnieć bez sprzeczności z własną istotą, to należy przyjać, że istnieje.

Przez całe średniowiecze refleksja teologiczna mocno wspierała naukowe dociekania związane z tematyką istnienia, poznania Boga czy zgłębiania tajemnic wiary. Wpływ myśli średniowiecznej na umysłowość epok późniejszych, choć negowany i pomniejszany, jest widoczny i trudny do przecenienia. Żadnemu okresowi ludzkich dziejów nie udało się tak subtelnie przezwyciężyć napięć i wypracować tak znakomitego i niespotykanego nigdy wcześniej i nigdy później kompromisu między wiedzą i wiarą. Relacja ta w nowożytności uznana została za wysoce sprzeczną, niezgodną ze standardami nowoczesnego, postępowego myślenia. Jak na ironię rozum, który św. Anzelmowi i jemu podobnym pozwalał głębiej wierzyć i lepiej poznawać Boga, w nowożytności stał się skutecznym, aczkolwiek zgubnym narzędziem wyzwalania człowieka spod zabobonnego myślenia o tym, co przedmiotem rozumowania być nie może. W Boga i całą otoczkę nadprzyrodzonej rzeczywistości można było co najwyżej wierzyć. Ludzki rozum miał odtąd koncentrować się na poznawaniu człowieka, poznawaniu świata i dostosowywaniu go do stale rosnących pragnień i potrzeb. Boga zaś, jako wytwór zbędny, umieszczono w bezpiecznej i kontrolowanej sferze ludzkiej świadomości. Konsekwencje tego drastycznego rozłamu odczuwa człowiek po dzień dzisiejszy, wciąż mówiąc „nie” Bogu, a „tak” światu.

\section{NOWOŻYTNOŚĆ - BÓG „WYMYŚLONY”}

Nowożytny umysł nie przyjął Boga, widząc w Nim relikt starego systemu wierzeń i myślenia mocno zniewolonego przez wiarę. Zanegował chrześcijańską prawdę o osobowym Bogu - centrum wszechświata, od którego człowiek wyszedł i ku któremu zmierza. Nie przyjął prawd objawionych i filozoficznych spekulacji, pozostających pod wpływem nauki świętej. Odrzucił starożytne autorytety, wyśmiał tradycję, zbojkotował tak ważne w średniowieczu postrzeganie świata przez pryzmat wiary, skorygował myślenie, przestawiając je na racjonalno-empiryczne tory, zakwestionował dualistyczny podział świata na materialny i nadprzyrodzony, Bogu zaś, o ile zupełnie nie zakwestionował Jego istnienia, 
wyznaczył jedynie marginalną rolę, pozostającą w zgodzie z ludzkim rozumowaniem. Odciął się radykalnie od tego, co transcendentne, nadprzyrodzone, niepewne, nieudawadnialne rozumowo czy niepoznawalne zmysłowo, na rzecz tego, co jasne, pewne, niepodważalne, racjonalne i sprawdzalne. Człowiek nowożytny uznał, że Bóg jako twór tak niepewny co do istnienia, jak i związków łączących Go z człowiekiem i światem, jest mu w zasadzie do niczego niepotrzebny.

Odczucia te potęgowały rozumowe osiągnięcia i dokonania człowieka na polu nauki czy techniki, które utwierdzały go w przekonaniu o własnej samowystarczalności, pozwalały całkiem sprawnie i dobrze egzystować bez nadprzyrodzonych odniesień. Co więcej, na wiele pytań, na które odpowiedzi dawała dotąd wiara i religia, znaleziono racjonalne wyjaśnienia. Heliocentryczna intuicja Mikołaja Kopernika usunęła Ziemię z centrum wszechświata, podważając tym samym jej uprzywilejowane miejsce w kosmosie. Akcentowane zaś w Biblii stworzenie człowieka na obraz i podobieństwo samego Boga, podkreślanie jego wyjątkowej, z tego aktu wypływającej pozycji, zakwestionowane zostały przez popularna, bo całkiem dobrze wytłumaczalną teorię Karola Darwina, znajdującą człowieka jako produkt tysięcy lat ewolucji, byt niewiele różniący się od zwierząt, w odniesieniu do którego nie można było mówić o jakiejś szczególnej godności czy wartości. Psychologiczne odkrycia Zygmunta Freuda, dowodzące że człowiekiem rządzą niskie, biologiczne instynkty, ten pogląd dodatkowo ugruntowały. To racjonalne objaśnianie świata, stopniowe poznawanie reguł nim rządzących, umiejętność panowania nad natura, pozwoliło człowiekowi uwierzyć we własną wielkość i wytworzyć do dziś pokutujące przekonanie, że można obyć się bez Boga, Jego prawd, praw i zasad ${ }^{10}$. Nieomylność, którą w starożytności przypisywano wielkim filozofom, w średniowieczu zaś papieżowi i Pismu Świętemu, w nowożytności należała do ludzkiego rozumu.

Tak jak w światopoglądzie chrześcijańskim człowiek silnie związany był z Bogiem, żył dla Boga, uznawał Jego niezależne istnienie, tak w nowożytności Bóg istniał dla człowieka, usytuowany w obrębie jego umysłu, ograniczony do ludzkiej świadomości stał się zakładnikiem ludzkiego rozumu. Tę prawdę o Bogu, Jego dziełach i związkach z ludzkością, którą wierzący chrześcijanin wyczytał z kart Pisma Świętego - skarbnicy wiedzy o Bogu, nowożytny racjonalista starał się odnaleźć we własnym rozumie. Postrzegając racjonalnie rzeczywistość, nie mógł przecież uwierzyć w te niewiarygodne, na poły mitologiczne historie ze Starego czy Nowego Testamentu.

Przełom w nowożytnym postrzeganiu Boga dokonał się za sprawą Kartezjusza. Z jego tezami, w mniejszym bądź większym stopniu, zgodzili się inni myśliciele. Kartezjański samoświadomy podmiot myślący wytworzył Boga we włas-

${ }^{10}$ Por. A. Bloom, Umyst zamknięty: o tym, jak amerykańskie szkolnictwo wyższe zawiodło demokrację i zubożyło dusze dzisiejszych studentów, tłum. T. Bieroń, Poznań 1997, s. 305nn. 
nym umyśle. Najpierw potwierdził własne istnienie, wnioskując o nim z myślenia, stąd słynne cogito, ergo sum, następnie, niejako z logicznej konieczności, założył istnienie Boga. Skoro myślę, wnioskował Kartezjusz, muszę istnieć, musi bowiem istnieć ktoś, kto tę czynność spełnia - podmiot myślący, on zaś musi mieć przyczynę swego istnienia, którą Kartezjusz upatrywał w Bogu, zgodnie $\mathrm{z}$ zasadą, że skutek musi mieć przyczynę. Bóg istniał więc w umyśle, lecz nie w sercu nowoczesnego, oświeconego światłem rozumu człowieka. Jednocześnie Jego istnieniu starano się nadać bardziej zracjonalizowane ramy. Odrzucono pielęgnowane dotąd mniemanie o świecie rządzonym przez Boga, zależnym od Niego czy o Bogu podtrzymującym go w istnieniu. Zmieniło się bowiem diametralnie postrzeganie świata $\mathrm{w}$ nowożytności. Postęp w dziedzinie astronomii, matematyki, fizyki czy przyrodoznawstwa dokonany za sprawą Kopernika, Keplera, Galileusza, Newtona czy Kartezjusza, utwierdził człowieka nowej ery w przekonaniu, że wszechświat to jedynie doskonały mechanizm, wyspecjalizowana maszyna, która rządzi się swoimi prawami, co więcej prawa te da się odkryć, a w konsekwencji panować nad światem. Człowiek zastąpił Boga, więcej, powoli dokonywało się to, o czym w XIX wieku powiedział Feuerbach: człowiek stworzył Boga i Bogiem jest dla samego siebie. Im więcej posiadł wiedzy, tym mniej miał wiary. Drogi wiary i wiedzy rozeszły się bezpowrotnie.

W rezultacie jednak w nowożytności, obok całkowitej niewiary i negacji Boga, głoszonych w poglądach m.in. Juliena O. de La Mettriego, Ludwiga Feuerbacha, Karola Marksa czy Fryderyka Nietzschego, przeważyła postawa deistyczna oparta na argumentacji fizyko-teleologicznej. Bogu, nie do końca mogąc Go zignorować i nie do końca mogąc wyjaśnić powstanie wszechświata, przypisano jednak pewną rolę - widziano w Nim przyczynę jego zaistnienia, poniekąd także gwaranta ładu i porządku na świecie. Z tą tezą racjonalny umysł mógł się początkowo zgodzić. Newton, postrzegając świat jako doskonałą maszynę, uznał, że musi ona być dziełem równie doskonałego umysłu. Podobnie mniemał Kartezjusz, a z filozofów późniejszych choćby Gottfried Leibniz, któremu Bóg jawił się jako doskonała monada, Wolter określający Boga mianem doskonałego, wiekuistego geometry wszechświata czy Immanuel Kant, dla którego Bóg był konieczny, aby mógł istnieć porządek moralny i etyczny.

Bóg nowożytnych stał się więc na nowo jedynie Najwyższą Istotą Rozumną, Zegarmistrzem świata, Najwyższym Inżynierem, na tym jednak Jego rola się kończyła. Stworzył świat, lecz pozostawił go samemu sobie, wycofał się z ingerencji w jego dalsze działania. Tak silna więź łącząca Boga, człowieka i świat w średniowieczu, w nowożytności została zerwana. Człowiek sam zdolny był i gotowy przejąć obowiązki Boga. 


\section{REFORMACJA}

Niewątpliwie niemały wpływ na taką postawę nowożytnego człowieka względem Boga, instytucji Kościoła czy wiary miał XVI-wieczny ruch religijno-społeczno-polityczny zwany reformacją ${ }^{11}$. Zbuntowany ludzki indywidualizm wywołał brzemienną w długofalowe skutki, niebezpieczną rewolucję. Jej twórca, Marcin Luter nieświadomie osiagnął skutek odwrotny od zamierzonego. Postulowane przez niego odnowienie chrześcijaństwa i powrót do pierwotnych źródeł poprzez całkowite wyzwolenie się jednostki spod władzy zdemoralizowanego Kościoła zaowocowało falą sekularyzmu, która zalała znaczną część Europy. Konsekwencje tej katastrofalnej w dziejach ludzkości powodzi, niszczącej jedność chrześcijańskiego Zachodu, odczuwalne są po dzień dzisiejszy. Kościół ze swoją nauką, swoimi wątpliwymi praktykami i sakramentami nie jest człowiekowi do niczego potrzebny głosił Luter. Pismo Święte, odczytywane w sposób dosłowny, łaska i osobista relacja łącząca wierzącego z Bogiem dają szansę na zbawienie. Przy tym grzeszny gatunek ludzki, z góry niejako, niezależnie od swojego wkładu uczynkowego czy czynionych w tym względzie starań, predestynowany jest do zbawienia lub potępienia. Idea „kapłaństwa wszystkich wiernych” pozostawiała sumieniu rozstrzyganie w kwestiach wiary, czyniąc go w tych sprawach autorytetem. W rezultacie zwolennicy rewolty Lutra ze swoimi religijnymi wątpliwościami pozostawieni zostali sami sobie. Pozbawieni gotowych, dogmatycznych rozwiązań, jakie dawała wypracowana przez stulecia tradycja kościelna, zatapiali się $\mathrm{w}$ religijnym pluralizmie, łatwo ulegali sceptycyzmowi, by w końcu zatonąć w zliberalizowanym myśleniu.

\section{REWOLUCJA FRANCUSKA}

Ateistyczne idee oświeceniowe, z najsilniej wyakcentowaną, fałszywie rozumianą wolnością jednostki, stały się podłożem, na którym wyrosły wszystkie zgubne, utopijne ideologie, stawiające sobie za cel pozostawienie człowieka samemu sobie i wpojenie mu przekonania, że on sam, wedle własnego rozumu, nieograniczony jakimikolwiek zasadami moralnymi czy nakazami, zdolny jest do tego, aby rządzić światem. Oświeceniowy program filozoficzny wcieliła w życie rewolucja francuska, radykalnie negując wszystko to, co dla człowieka ważne, to, co go od wieków otacza, co stanowi istotę jego człowieczeństwa. Rewolucyjna gilotyna w swym morderczym szale stracić miała bezpowrotnie historię, tradycję, obyczaj, autorytet, przywiązanie człowieka do wartości i religii. W szcze-

${ }^{11}$ Zob. J. Delumeau, Narodziny i rozwój Reformy protestanckiej, t. 1, tłum. J.M. Kłoczkowski, Warszawa 1986. 
gólny sposób jej ostrze skierowało się przeciwko Kościołowi hierarchicznemu, widząc w nim praźródło ucisku, zniewolenia i ograniczenia człowieka. Paradoksalnie, w imię wzniosłych haseł: wolności, równości, braterstwa, rewolucyjna Francja pod coraz to nowymi rządami dokonywała krwawych rzezi swoich obywateli, nie szczędząc przy tym nawet króla oraz samych rewolucjonistów. Wraz z obaleniem starego społeczno-politycznego porządku domagano się zmiany religii na taka, która pozostawałaby w zgodzie w ateistycznymi wytycznymi. Rewolucja stworzyła nową religię przeciwną katolickim wartościom. Jej arcykapłanem obwołał się Maximilien de Robespierre, Boga zaś zastąpił kult Istoty Najwyższej, która według nowego, postępowego myślenia stworzyła świat dla wolności i demokracji.

Nie sposób dziś nie dostrzec zgubnego wpływu rewolucyjnych dokonań na przyszłe pokolenia. Wolność i demokracja przeinterpretowane w okresie rewolucji francuskiej doprowadziły do zlaicyzowania Europy i stały się iskrą zapalną dla większości fanatycznych ideologii ${ }^{12}$, takich jak: komunizm, faszyzm, nacjonalizm, modernizm, postmodernizm czy liberalizm.

Wpisane w naturę człowieka ukierunkowanie na transcendentny wymiar egzystencji, tak silnie tłumione w nowożytności, nie pozwala na całkowite wyeliminowanie Boga z przestrzeni ludzkiego życia. Jeśli jednak człowiek nowożytny zakłada istnienie Boga, to tylko takiego, który nie wtrąca się w jego sprawy i nie ingeruje w jego działania. Stwarza Bogu wygodne dla siebie miejsce, jedynie takie pole istnienia, jakie wyznacza Mu ludzki umysł. Przypisane odwiecznie role odwracają się - to Stwórca istnieje dla swojego stworzenia, nie zaś stworzenie dla Stwórcy. Idea Boga istniejącego w bezpiecznych granicach, jakie wyznacza Mu człowiek, rzutuje na osobę Jego Syna Jezusa Chrystusa. Nowożytny umysł, mówiąc stanowcze "nie” temu, co nadprzyrodzone, niezgodne z rozumem i doświadczeniem, nie jest zdolny do przyjęcia prawdy o Bożym człowieczeństwie. $\mathrm{O}$ ile, paradoksalnie, może jakoś z trudem wytłumaczyć sobie istnienie Boga, którego nie widzi, o którym nic powiedzieć nie może, o tyle nie jest w stanie zaakceptować Boga, który zaistniał w materialnym świecie i dał się człowiekowi poznać. Bóg, będący w nowożytnej filozofii idea, wytworem umysłu, z oczywistych względów nie może być bytem realnie istniejącym, stającym się jednym z ludzi. Wytwór umysłu nie może się zmaterializować. Wcielenie Syna Bożego budzi kontrowersje i wątpliwości, których światły umysł przezwyciężyć nie może. Oto Dziewica, nieznająca fizycznego kontaktu z mężczyzną rodzi Syna, z materii, której dostarcza Duch Święty niebędący ojcem dziecka ${ }^{13}$. Następuje tu

${ }^{12}$ Więcej na temat genezy, przebiegu, wpływu idei propagowanych przez rewolucjonistów francuskich na zbrodnicze ideologie XIX i XX wieku, a także współczesność, zob. M. Poradowski, Dziedzictwo rewolucji francuskiej, Wrocław 2001.

${ }^{13}$ Por. Breviarium Fidei..., s. 105. 
konfrontacja umysłu z tajemnicą Trójcy Świętej. Co więcej, Syn dokonuje niezwykłych znaków, czyni cuda, których żaden człowiek uczynić nie może. Jakby tego było mało, pokonuje barierę śmierci, ukazując się żywy pośród ludzi. Nie ma logicznego wyjaśnienia tych zjawisk. Kimże więc jest ów człowiek, w którym chrześcijanie widzą Syna Bożego?

\section{TEOLOGIA LIBERALNA I PLURALISTYCZNA}

Wskazując choćby tylko na postrzeganie Chrystusa w teologii liberalnej powiązanej z francuskim i angielskim deizmem, kartezjańskim racjonalizmem, naturalizmem, niemieckim idealizmem oraz transcendentalizmem, czy w teologii pluralistycznej o zabarwieniu relatywistycznym będącej połączeniem nurtów filozofii Zachodu, szczególnie okresu oświecenia, z filozofiami i religiami Dalekiego Wschodu ${ }^{14}$, można powiedzieć, że Chrystus jawi się w nich jedynie jako bardziej doskonały człowiek, nie zaś Bóg, gdyż objawienie się osobowego Boga jest tu niemożliwe. Wspólnym zresztą mianownikiem tych poglądów jest zakwestionowanie wyjątkowej roli chrześcijaństwa jako religii nadrzędnej, a przypisanie jej statusu jedynie jednej $z$ wielu innych, naturalistyczne ujmowanie osoby Jezusa Chrystusa z podważeniem Jego boskiej świadomości, relatywizacja prawdy, która przestaje być absolutna, a staje się uzależniona od wielu czynników, czy metafizyczny sceptycyzm, krytycznie podchodzący do wszelkich źródeł objawienia.

Generalnie teologie te, z nielicznymi wyjątkami, jak choćby Artura Drewsa mówiącego o micie „cierpiącego Boga - odkupiciela”, z którego wyrosło chrześcijaństwo, uznają istnienie historycznego Jezusa, odmawiają Mu jednak boskiego pochodzenia. Widzą w Nim wzór doskonałego umiłowania Boga, prawdziwego człowieczeństwa, wyjątkowy przykład życia zgodny z wolą Bożą, nauczyciela, osobowość porywającą tłumy, miłośnika prawdy, głosiciela Królestwa Bożego, którego działalność wywarła ogromny wpływ na otaczających Go. Stąd rzekome zbawcze dzieło Jezusa, to nic innego, jak tylko mitologiczna opowieść wymyślona przez tych, którzy bardzo chcieli w nią uwierzyć, którym fanatyczna egzaltacja domniemanym Synem Bożym odebrała zdolność zdroworozsądkowego myślenia.

Człowiek wciąż, nawet na gruncie teologii, podejmuje próby racjonalizowania wiary, takiego przeinterpretowywania, manipulowania prawowierną nauką Kościoła, aby była ona zgodna z ludzkim rozumowaniem, aby była przez ten rozum możliwa do strawienia, możliwa do zaakceptowania. Człowiek nowożyt-

\footnotetext{
${ }^{14}$ Szczegółowo zagadnienie postrzegania Jezusa Chrystusa w teologii liberalnej i teologii pluralistycznej omawia I.S. Ledwoń, por. tegoż „...i nie ma w żadnym innym zbawienia”: wyjatkowy charakter chrześcijaństwa w teologii posoborowej, Lublin 2006, s. 65-71, $211 \mathrm{nn}$.
} 
ny, dla którego jedynymi pewnymi narzędziami poznawczymi stały się rozum i empiria, nie chce i nie może dopuścić do siebie myśli o tym, że istnieje coś, co z tych bezpiecznych, kontrolowanych przez niego kategorii zostało wyłączone, że istnieje inny, nadprzyrodzony wymiar niemierzalny ani rozumem, ani doświadczeniem, a który jest zarezerwowany tylko i wyłącznie dla wiary, tej wiary, którą człowiek postępu i nowoczesności w pędzie za własną wielkością zatracił, zagubił. Przekreślając wypracowany w średniowieczu kompromis rozumu i wiary, skutecznie zamknął się na prawdę. Tak wielki opór i sprzeciw budzą w człowieku wydarzenia zbawcze. Tymczasem istota, sensem, fundamentem chrześcijaństwa jest wiara w Jezusa Chrystusa, w Jego wcielenie i zmartwychwstanie, wiara w to, że jest On prawdziwym Bogiem, który przyszedł na ziemię, i wiara w to, że tylko dzięki zbawczej ofierze Krzyża człowiek może osiagnąć zbawienie. I taka prawda jest zupełnie niezależna od ludzkiego jej uznania bądź nie.

\section{IDEOLOGIA POSTMODERNISTYCZNA}

Trudno jednoznacznie zdefiniować tak niejednorodny i wielowątkowy termin, jakim jest postmodernizm ${ }^{15}$. Etymologia tego słowa pochodząca od łacińskiego zwrotu modo 'teraz', 'niedawno', odnosi się do tego, co dzieje się w danej chwili, blisko, bezpośrednio, wskazując jednocześnie na zmienność, chaotyczność, płynność, niedookreśloność teraźniejszości, stojącej w wyraźnej sprzeczności ze statyczną, uporządkowaną przeszłością. Ten zespół prądów, poglądów, zasad, interpretacji, zachowań, tendencji, przejawiających się w każdej dziedzinie ludzkiego życia, charakteryzuje się tak dużym stopniem otwartości, że rzeczywistość i poznanie jawią się jako niekończący się, podatny na ciągłe zmiany proces, który dobrze oddaje starożytna Heraklitejska zasada wskazująca na zmienność, nieustanne stawanie się, wieczny ruch, jako wyznaczniki rzeczywistości. Nic zatem nie jest, a wszystko staje się. Takie jej ujęcie prowadzi do katastrofalnego w skutkach, wszechobecnego relatywizmu, uprawniającego każdego do dowolnych, zgodnych z jego wyobrażeniami, interesami czy poglądami interpretacji i przewartościowaniem rzeczywistości. Stały, stabilny, wypracowany w przeszłości obraz rzeczywistości, opartej na solidnych fundamentach, w umysłowości postmodernistycznej staje się terenem nieustannego balansowania, niepewności, daremnego poszukiwania nowych wzorców, na których mógłby się oprzeć. Odrzucenie i zanegowanie czasu, historii, tradycji, prawd absolutnych, fundamentalnych, egzystowanie jakby „poza” tym wszystkim, co znane, pewne, sprawdzone, prowadzi do tworzenia substytutów, zastępników nowego porządku świata.

${ }^{15} \mathrm{O}$ genezie postmodernizmu, jego filozofii, postawie wobec prawdy, koncepcji człowieka i życia społecznego, oraz sprzeciwianiu się religii i Bogu, zob. S. Kowalczyk, Idee filozoficzne postmodernizmu, Radom 2004, s. $7 \mathrm{nn}$. 
Wymieniając tylko niektóre z elementów postmodernistycznego światopoglą$\mathrm{du}^{16}$, należy wskazać na: specyficzny stosunek człowieka postmodernistycznego do Boga, poszukiwanie nowych form religijności, stawianie znaku równości między religiami, wierzeniami czy sektami, istnienie wielu, nierzadko sprzecznych prawd i praw, których twórcą staje się sam człowiek, kreując siebie na najwyższego i jedynego ustawodawcę, odrzucenie zasad etycznych, moralnych, religijnych, podważenie celowości, sensu ludzkiej egzystencji i uznanie, że wszystko jest dziełem przypadku, życie horacjańską chwila, łatwą, lekką i przyjemną, pogonią za dobrami materialnymi, zanik prawdziwych więzi międzyludzkich opartych na miłości, wrażliwości i poszanowaniu drugiego człowieka, patrzenie na człowieka przez pryzmat tego, co posiada, a nie tego, kim jest, propagowanie tolerancji, rozumianej jako akceptacja wszelkich dewiacyjnych, patologicznych form zachowania i thumaczenie ich postępowym, nowoczesnym myśleniem. Warto wymienić również: gloryfikowanie nieograniczonej ludzkiej wolności, przyzwalającej na wszystko, na co tylko ma się ochotę, uciekanie ze świata rzeczywistych, realnych problemów, z którymi trzeba się zmierzyć, do świata wirtualnej cyberprzestrzeni, braku odpowiedzialności i nieponoszenia konsekwencji swoich działań, zastępowanie wychowania dzieci i młodzieży wspieraniem, zgodnie z założeniem, że proces wychowywania jest tylko źródłem ograniczeń, ucisku, stresu, młody człowiek sam umie pokierować swoim życiem, nie potrzebuje żadnych autorytetów, nakazów czy zakazów, a jedynie wspierania go w tym, co sam uzna za najlepsze dla siebie, degradacja współczesnej kultury, którą odrywa się od jej wielowiekowego dziedzictwa, odrzucanie perspektywy życia wiecznego, negowanie doświadczeń granicznych, w szczególności śmierci, obsesyjny lęk przed nią, życie tu i teraz, tak, jak gdyby wymiar nadprzyrodzony nie istniał.

Wyliczenie to można by oczywiście z powodzeniem kontynuować, dopisując do tego ponurego katalogu kolejne przerażające punkty. Wydaje się to jednak bezcelowe. Bardzo trafnie trudną kondycję człowieka uwikłanego w ponowoczesne myślenie nakreślił G. Ravasi, pisząc:

$\mathrm{Z}$ jednej strony fragmentacja, niespójność, indyferencja, pustka wewnętrzna, relatywizm i subiektywizm, $\mathrm{z}$ drugiej strony jedyne w swoim rodzaju i ekstremalne zwrócenie się ku technice i rzeczywistości wirtualnej, zimnym arbitrom ludzkiej egzystencji: oto dramatyczny koszmar nowoczesnego społeczeństwa, które aspiruje do uwolnienia się od względności i skończoności ${ }^{17}$.

\footnotetext{
${ }^{16}$ Por. S.I. Możdżeń, Fatszywe drogi wychowania, Sandomierz 2013, s. 288-301.

${ }^{17}$ G. Ravasi, Wcielenie i nowoczesność. Analiza kontrapunktu, „Przegląd Uniwersytecki” 2012, nr 5 (139), s. 14.
} 
Godne pożałowania jest to dramatyczne rozdarcie człowieka postmodernistycznego ${ }^{18}$, który z jednej strony bezkrytycznie zaufał doczesnemu światu materialnemu, z drugiej zaś nie może całkowicie i ostatecznie wyzbyć się wpisanej w jego istotę duchowości. Zarysowana powyżej ludzka, racjonalno-religijna odpowiedź na Bożą ingerencję w historię człowieka, począwszy od realnego przyjścia Boga na świat w osobie Jezusa Chrystusa, ciagłego wyczekiwania Go przez naród wybrany, do postrzegania Boga w starożytności, średniowieczu czy czasach nowożytnych dowodzi religijnej natury człowieka, który jest istotą zdolną nie tylko do ziemskiego, ograniczonego czasem trwania, ale przede wszystkim do wychodzenia na spotkanie ku światu nadprzyrodzonemu, i to niezależnie od tego, czy tego chce czy nie, czy jest tego świadomy czy nie, czy wiara jedynie tli się w nim, zagłuszana podszeptami rozumu, czy też płonie żywym ogniem. Trwa więc człowiek ponowoczesny w odrętwieniu, zawieszony gdzieś pomiędzy doczesnością a wszczepioną weń tęsknotą za innym wymiarem. Próbując przełamać ten marazm, organizuje sobie życie duchowe, szukając wsparcia w pluralistycznych i świeckich tendencjach epoki. Wiara w chrześcijańskiego Boga w jej tradycyjnym, znanym, ugruntowanym kształcie jest trudna do przyjęcia i zaakceptowania, nierzadko też ustępuje miejsca nowym formom religijności.

Jeśli człowiek postmodernistycznej rzeczywistości widzi gdzieś miejsce dla Boga, to jedynie, o czym wspomina przywołany już Benedykt XVI, w sferze myśli czy idei, nie zaś w materialnym świecie, do którego Bóg zwyczajnie nie pasuje. Dlatego próbuje gdzieś „wepchnaćc” swojego Stwórcę, aby Ten mu nie przeszkadzał, nie był zagrożeniem dla jego absolutnej, nieograniczonej wolności. W postmodernistycznym świecie zmienia się diametralnie postrzeganie Boga $^{19}$, na nowo według ludzkich oczekiwań i wyobrażeń kształtuje się Bosko-ludzką relację. Niekwestionowany niegdyś autorytet Kościoła ulega podważeniu, a on sam w oczach wielu staje się jedynie czysto ludzką instytucją, realizująca własne polityczno-społeczno-gospodarcze interesy. Praktyki religijne zatracaja swój duchowy wymiar, stając się odświętnie kultywowaną tradycją „dla oka" i na pokaz, a nie wewnętrznym przeżyciem mającym zbliżać do Boga. W ponowoczesnej logice Bóg traci swe transcendentne oblicze, przestaje być Bogiem osobowym, nie wpływa na losy świata, nie ingeruje w ludzkie życie, opatrzność Boża nie roztacza się nad człowiekiem i światem, odarty zostaje z boskich atrybutów, Jego prawa, nakazy i zakazy rażą, wydają się nieaktualne, przestarzałe i niedostosowane do wymogów współczesności, oderwany zostaje od hierarchicznego Kościoła, który sam ustanowił. Tym samym człowiek postmoderny,

\footnotetext{
${ }^{18}$ Zob. Ch. Delsol, Esej o człowieku późnej nowoczesności, tłum. M. Kowalska, Kraków 2003.

${ }^{19}$ Postmodernistyczny obraz Boga kreśli S. Wielgus, por. tenże, Stanqć po stronie dobra, Sandomierz 2013, s. 157-159.
} 
mówiąc „tak” specyficznie rozumianemu Bogu, a „nie” Kościołowi, odrzuca depozyt wiary na ręce tego Kościoła złożony, zaprzepaszcza łaskę jedynego, pełnego, możliwego w ziemskich warunkach zjednoczenia $\mathrm{z}$ Bogiem. Popada w swego rodzaju niebezpieczną schizofrenię, przeciwstawiając sobie to, co przeciwstawione być nie może, jest bowiem nierozerwalnie ze sobą złączone. Nieświadomie staje się niekiedy kontynuatorem poglądów M. Lutra, relację z Bogiem zawężając do osobistego przeżycia, a artykuły wiary pozostawiając własnej interpretacji. Bóg oderwany od Kościoła, źródła Jego najpełniejszego poznania, staje się bezosobowym bytem, jakąs istniejącą gdzieś siłą, energią, mocą.

Odrzucając osobowego Boga obecnego w Kościele, sakramentach, przykazaniach, traktując wiarę w sposób instrumentalny jako narzędzie mające służyć lepszemu, wygodnemu życiu, człowiek wystawia się na pokusę zaprzedania się nowym, starym bożkom. Skłonny jest uwierzyć, że wszystkie religie, wyznania, duchowe praktyki, obrzędy mają taką samą wartość, są sobie równe. Ulega fascynacji współczesnymi kulturalno-społeczno-politycznymi ideologiami i kultami urastającymi do rangi nowych religii. Poszukuje nowych duchowych inspiracji, przyznając sobie w tej sferze większą autonomię. Postmodernizm, odpowiadając na to złudne, ludzkie zapotrzebowanie, proponuje szerokie spektrum takowych doznań. Ożywają w nowej odsłonie praktyki doby starożytnej - epoki hellenistycznej i klasycznej Grecji, zainteresowaniem cieszą się tradycje mistyczne hinduizmu i buddyzmu, tradycje duchowe rdzennej Ameryki i neolitycznej Europy, modne stają się praktyki ezoteryczne, takie jak: alchemia, astrologia, joga czy kabała $^{20}$.

Człowiek doby postmodernistycznej, funkcjonujący równocześnie w cyberprzestrzeni, stykający się z niewyobrażalnie rozwijającą się techniką, nie ma dziś większych problemów $\mathrm{z}$ wiarą $\mathrm{w}$ tę zdeformowaną transcendencję, jaką proponuje mu świat. Jest w stanie przyjąć istnienie równoległych cywilizacji, wyczekuje przybycia istot z kosmosu, uzależnia swój los od horoskopów, przepowiedni, wróżb, jest w stanie uwierzyć w najbardziej nawet absurdalne i nieprawdopodobne programy duchowego rozwoju, które proponują sekty ${ }^{21}$, ślepo podąża za tzw. pseudoautorytetami, idolami - kreatorami masowej wyobraźni, niemalże z namaszczeniem nawiedza olbrzymie centra handlowe - współczesne świątynie masowej konsumpcji. Ci, którzy realnie, poprzez dostępne środki - prasę, mass

${ }^{20}$ Więcej na temat nowych form religijnych i duchowości postmodernistycznej zob. R. Tarnas, Dzieje umysłowości zachodniej: idee, które uksztaltowały nasz światopoglad, tłum. M. Filipczuk, J. Ruszkowski, Poznań 2002, s. 474-475.

${ }^{21}$ Zagrożenia, jakie niesie ruch New Age, widziane oczyma jednego z jego bardziej znamienitych członków, zob. R.N. Baer, W matni New Age, w: W matni New Age; New Age - kultura i filozofia, tłum. J. Kłos, Kraków 1996, s. 5-294; o kulturze i filozofii New Age zob. S. Rouvillois, New Age - kultura i filozofia, w: W matni New Age; New Age - kultura i filozofia, thum. K. Mądel, K. Skorulski, Kraków 1996, s. 306-427. 
media ${ }^{22}$, kształtują myślenie współczesnego człowieka, umiejętnie grają i manipulują tą jakże delikatna, intymną i niesłychanie ważną sferą ludzkiej egzystencji. Ogromne siły i środki zaangażowane są dziś w tworzenie i organizację wykrzywionej płaszczyzny duchowej, w podsuwanie człowiekowi podatnemu na tego typu działania gotowych odpowiedzi i ustalonych wzorców rozwiązywania problemów, w mówienie mu, w co ma wierzyć. Duchowość człowieka nowoczesnego ulega skomercjalizowaniu, staje się ładnie opakowanym towarem, który można łatwo kupić i sprzedać. Wystarczy wspomnieć o cieszącym się z roku na rok większym zainteresowaniem tzw. święcie Halloween, z powodzeniem przeszczepionym na grunt polski, mającym być w założeniu przeciwwagą dla Uroczystości Wszystkich Świętych. Ubrane w konwencję wesołej, kostiumowej zabawy - „cukierek albo psikus”, symbolizowane przez wampiry, duchy, czarownice, trupie czaszki i popularną dynię z umieszczonym weń światłem, to jakże modne, lecz wątpliwe święto, mające swe źródło w kultach pogańskich, jest niczym innym, jak tylko świętem ku czci Szatana, lucyferycznym hołdem składanym mu w postaci krwawych, niewinnych ofiar.

Ten, kto posiadł ludzkie sumienie, zawładnął całym człowiekiem. Tak kształtująca się w człowieku duchowość nie czyni go prawdziwie wolnym, lecz niesie zniewolenie. Człowiek o wykrzywionej duchowości, ograniczony czasem i przestrzenią, jak celnie zauważa Gianfranco Ravasi, gubi się w momencie zbliżania się do autentycznej tajemnicy, odczuwa lęk wobec rzeczywistości „ostatecznych” takich jak: Bóg, życie, cierpienie, ból, śmierć i życie po śmierci² ${ }^{23}$. Nie rozumie sensu cierpienia, nie godzi się na chorobę, ból, często wybierając ostateczne rozwiązania, nie potrafi z godnością pogodzić się ze starością, próbując wszelkimi metodami zachować młodość, odczarowuje śmierć, tak, jakby to graniczne doświadczenie miało go nigdy nie dotknąć, wątpi w życie po śmierci. Wobec tych trudnych doświadczeń, które są nieodzowną własnością ludzkiej egzystencji, staje całkowicie bezradny, bezbronny. Jedyną nadzieją na wydobycie człowieka postmodernistycznego z tej pustki, chaosu, marazmu jest wiara w Jezusa Chrystusa wcielonego i zmartwychwstałego, gdyż On uzdrawia poranioną ludzką naturę, wyzwala z ciemności grzechu, przywraca człowiekowi jego utraconą wartość i godność dziecka Bożego. Jego wcielenie nadaje właściwy i prawdziwy sens i cel ludzkiemu życiu, Jego zmartwychwstanie sprawia, że śmierć nie jest kresem, nicością, a przejściem $z$ tego świata do innego: „życie Twoich wiernych, Panie, zmienia się, ale się nie kończy”. Ludzka egzystencja nabiera nowego wymiaru, jeśli opiera się na wzorze Chrystusowego życia, jeśli staje się respektowaniem Jego woli, wypełnianiem Jego nauki.

${ }^{22}$ Więcej o technikach manipulacyjnych i propagandowych stosowanych współcześnie, zob. T. Janka, Manipulacja i propaganda w mass mediach źródtem fatszywego obrazu człowieka, świata i Boga, w: Studium franciscanum in caritate facere, red. T. Janka, Poznań 2009, s. 205-225.

${ }^{23}$ Por. G. Ravasi, Wcielenie i nowoczesność..., dz. cyt., s. 15. 
Wciąż jednak zdaje się, że człowiek postmodernistyczny, wzorem tych uczniów, którzy odeszli od Pana, gdyż niezrozumiałe i nie do przyjęcia było dla nich to, o czym nauczał, uparcie powtarza i pyta: „Trudna jest ta mowa. Któż jej może słuchać?" (J 6,60). Wielu też może się zwyczajnie wydawać, że życie zgodne z moralnymi nakazami, przestrzeganie Bożych przykazań, spełnianie praktyk religijnych jest zwyczajnie nudne, tak różne od tego, czym dziś nęci i mami człowieka współczesny świat. Znajdą się i tacy, dla których wizja wiecznego przebywania $\mathrm{z}$ Bogiem w wieczności jest jedynie wymysłem i pobożnym życzeniem chrześcijan.

Oświeceniowa rewolucja umysłowa na trwałe zaszczepiła w człowieku jakże błędne i zgubne mniemanie, że człowiek, wyposażony w to wspaniałe narzędzie, jakim jest rozum, doskonale poradzi sobie bez Boga. Konsekwencje takiego myślenia i działania wyraził Nietzsche, mówiąc, że człowiek zabił Boga w sobie i myślał, że ujdzie mu to bezkarnie. Owocem tego bezprecedensowego w dziejach ludzkości morderstwa stało się duchowe samobójstwo człowieka. Nowożytny duch, dla którego Boże tajemnice zbawienia były skandalem, poniósł całkowita klęskę. Zagubionego człowieka trudnej współczesności można dziś zapytać, parafrazując niezwykle trafną intuicję Pascala: człowieku, cóż masz do stracenia, jeśli wierzysz? Absolutnie nic. Przeciwnie, możesz tylko zyskać. Co jednak, jeśli nie wierzysz? Wtedy masz do stracenia absolutnie wszystko, stawiasz bowiem na szali swoje szczęście i życie wieczne.

\section{BIBLIOGRAFIA}

Baer R.N., W matni New Age, w: W matni New Age; New Age - kultura i filozofia, thum. J. Kłos, Kraków 1996.

Bloom A., Umyst zamknięty: o tym, jak amerykańskie szkolnictwo wyższe zawiodto demokrację i zubożyło dusze dzisiejszych studentów, tłum. T. Bieroń, Poznań 1997.

Breviarium Fidei. Wybór doktrynalnych wypowiedzi Kościoła, red. I. Bokwa, Poznań $2007^{3}$.

Delsol Ch., Esej o człowieku późnej nowoczesności, tłum. M. Kowalska, Kraków 2003.

Delumeau J., Narodziny i rozwój Reformy protestanckiej, t. 1, tłum. J.M. Kłoczowski, Warszawa 1986.

Janka T., Fatszywe rozumienie wolności we wspótczesnym świecie w kontekście praktyk przeciwko życiu, „Studia Franciszkańskie” 2012, nr 22, s. 35-60.

Janka T., Jana Dunsa Szkota pamiętny turniej średniowiecznej filozofii, Poznań 2011.

Janka T., Manipulacja i propaganda w mass mediach źródtem fałszywego obrazu człowieka, świata i Boga, w: Studium franciscanum in caritate facere, red. T. Janka, Poznań 2009, s. 205-225.

Kowalczyk S., Idee filozoficzne postmodernizmu, Radom 2004. 
Ledwoń I.S., „, ...i nie ma w żadnym innym zbawienia”: wyjątkowy charakter chrześcijaństwa $w$ teologii posoborowej, Lublin 2006.

Możdżeń S.I., Fatszywe drogi wychowania, Sandomierz 2013.

Poradowski M., Dziedzictwo rewolucji francuskiej, Wrocław 2001.

Ratzinger J., Jezus z Nazaretu Dzieciństwo, tłum. W. Szymona, Kraków 2012.

Ravasi G., Wcielenie i nowoczesność. Analiza kontrapunktu, „Przegląd Uniwersytecki” 2012, nr 5 (139), s. 12-15.

Rouvillois S., New Age - kultura i filozofia, w: W matni New Age; New Age - kultura i filozofia, tłum. K. Mądel, K. Skorulski, Kraków 1996.

Stefański J., My głosimy Chrystusa ukrzyżowanego, który jest zgorszeniem dla Żydów... (1 Kor 1,23), „Studia Gnesnensia” 2011, nr XXV, s. 27-44.

Tarnas R., Dzieje umystowości zachodniej: idee, które uksztaltowaty nasz światopoglą, tłum. M. Filipczuk, J. Ruszkowski, Poznań 2002.

Wielgus S., Stanać po stronie dobra, Sandomierz 2013.

\section{SUMMARY}

This article discusses two events from Jesus Christ's life: incarnation and resurrection. They constitute a problem in philosophy. These events in the light of Christian faith do not require the type of epistemological reasons, because it is the mystery of faith. In philosophy, however, up to this day they are analyzed by many philosophers and are getting rationalization. These events are a scandal for the modern philosophy, in the words of Pope Benedict XVI in his book Jesus of Nazareth, and counterpoint to the contemporary, as Cardinal Gianfranco Ravasi said.

\section{Keywords}

God, incarnation, resurrection, reformation, enlightenment, modernity, postmodernism

\section{Słowa kluczowe}

Bóg, wcielenie, zmartwychwstanie, reformacja, Oświecenie, moderność, postmodernizm 